Aborisade, W.T., A.T. Ajao, and A.F. Jimoh, Effect of Heat Treatment on Aflatoxin Contents of Tomatoes Samples in Ilorin, Kwara State, Nigeria. International Journal of Life Sciences and Biotechnology, 2020. 3(2): p. 18-26. DOI: 10.38001/ijlsb.664750

\title{
Effect of Heat Treatment on Aflatoxin Contents of Tomatoes Samples in Ilorin, Kwara State, Nigeria
}

\author{
Wakili Tope Aborisade ${ }^{*(D)}$, Abdullahi Taiwo Ajao1(i) ${ }^{1}$ Abimbola F. Jimoh ${ }^{1}$
}

\section{ABSTRACT}

Fungi contamination of agricultural products had been one of the major concerns to human due to their possibility of causing spoilage and the potential of producing potent toxins that could constitute health problems. Therefore, this study evaluates the effect of heat treatment on aflatoxin contents of tomatoes samples in some selected market in Ilorin, Kwara State, Nigeria. The spoilt and fresh tomatoes samples were randomly purchased from nine vendors for analysis. Fungi were isolated on Sabroud dextrose agar and identified using colonial and morphological characteristics. The levels of aflatoxin in the samples were determined using ELISA techniques and effects of heat treatments on aflatoxin levels of the samples were determined before and after 5, 15, 25 and 35 minutes of heat treatments at $100{ }^{\circ} \mathrm{C}$. The results revealed the presence of fungi contaminants in all the analysed samples irrespective of their quality status. Furthermore, the aflatoxins contaminants were not detected in all the evaluated fresh samples; whereas the presence of aflatoxin in the spoilt samples was observed. The average aflatoxin contents of spoilt samples were $7.83,8.17$ and $8.62 \mu \mathrm{g} / \mathrm{kg}$ respectively, with no significant differences among the values. The effect heat treatments on the aflatoxin contaminated samples were observed to be time dependent. About $7.5 \%$ non-significant reductions ( $p>0.05)$ in aflatoxin contents of the samples were observed after $5 \mathrm{~min}$ of heat treatment. While, significant reduction of about $45.0 \%, 53.1 \%$ and $71.5 \%$ were observed after 15,25 and 35 minutes of heat treatments respectively. This is an indication that proper cooking at 100 ${ }^{\circ} \mathrm{C}$, over a period of time could significantly reduce aflatoxin level in some food products that are usually subjected to cooking prior to consumption

\author{
ARTICLE HISTORY \\ Received \\ 25 December 2019 \\ Accepted \\ 28 November 2019
}

\section{KEYWORDS}

ELISA,

aflatoxins,

fungi,

heat,

tomatoes

\section{Introduction}

Fungi groups had been implicated in most of the post-harvest loss of some major agricultural products. However, the major concerns about fungi presence in agricultural produce did not limit to their possibility of causing spoilage but their capability to release the potent toxins into the products [1]. The toxins of fungi origin are generally termed mycotoxins and they are reported to be the secondary metabolites of fungi metabolism [2]. The groups of reported mycotoxins producing fungi include,

\footnotetext{
${ }^{1}$ Microbiology Unit, Department of Bioscience and Biotechnology, Kwara State University, Malete, Nigeria

*Corresponding Author: Wakili Tope Aborisade. e-mail: wakili.aborisade@kwasu.edu.ng
} 
Alternaria, Fusarium, Pencillium, Mucor and Aspergillus genera. They can flourish at relatively mild acidic $\mathrm{pH}$ range that characterized the vegetables and fruit products.

Aflatoxins are among the most reported group of mycotoxins with high prevalence rate in most of the food products. They had been reported to be a potential mutagene and carcinogene compounds. Also, they could have some cyototoxic, teratogenic effects on human as well as causing liver serosis and immune impairment among others [3].

Tomato (Lycopersicum esculentum) is an herbaceous plant of family solanaceae [4]. The richness of tomato in terms of its nutritional composition has made it a good source of nutrient not only for human consumptions but also for microorganisms. It has been reported to be a good source of vitamins and some other phytonutrients such as proteins, carbohydrates as well as minerals such as potassium [5]. The use of spoilt tomatoes for soup ingredients is one of the common practices especially among the lower and middle classes in Nigeria without considering its potential health implications. These could be attributed to socio-economic factors, believe and cultural factors among others. In recent year, Nigeria had been ranked among the poorest countries with highest poverty rate [6].

The consumption of aflatoxins containing spoilt tomatoes could endanger the people's life. It has been recently reported that the rising incidence of cancer among human could probably have direct linked with consumption of spoilt tomatoes [7, 8]. In Nigeria, the preparation of soup usually involves thorough cooking processes; therefore, this study was to evaluate the effect of heat treatments on the aflatoxin levels of spoilt tomatoes used in making soup.

\section{Material and Methods}

\section{Collection of Samples}

The spoilt and fresh tomatoes fruits samples sold in some selected major market in Iloin, Kwara State Nigeria, were randomly purchased from nine vendors for aflatoxin assay. These markets were Ipata market Ilorin East Local Government Area, Oloje Market, Ilorin West local Government Area and Kunlende market, Ilorin South Local Government Area. The tomatoes samples were transported aseptically in sterilized sampling bottles to the laboratory for further processing and analyses.

\section{Isolation and Identification of Fungi Group Present in Tomatoes Samples}


The isolation and identification of fungi present in tomatoes' samples were carried out by adopting the method used by Suleiman [9] with little modifications. About $1 \mathrm{~g}$ from homogenized samples was aseptically serially diluted up to 10 fold dilution. About 0.1 $\mathrm{ml}$ from diluted samples was inoculated by streaking methods onto plate of Sabroud dextrose agar (SDA) and incubated at room temperature for the period of 4 to 7 days. Each of the distinct fungus colony was sub-cultured onto the SDA plates and incubated at room temperature for 4 to 7 days.

For identification the colonies were observed from the upper and lower part of the plates and colonial characteristics were noted. The isolates were further subjected to microscopic examination using lactophenol cotton blue stain under the low (x 10) and high (x 40) power objective lens respectively. The morphology features like spore types and presence or absence of septa in the mycelia were observed.

\section{Effect of Heat Treatment on Aflatoxin Level of Tomatoes Samples}

The aflatoxin levels of tomatoes samples were determined prior to heat treatment and after 5, 15, 25 and 35 minutes of heat treatments at $100{ }^{\circ} \mathrm{C}$ in water bath under standard conditions.

\section{Extraction and Quantification of Aflatoxin in Tomatoes Samples}

The levels of aflatoxin in tomatoes were determined using standard ELISA techniques as described by Zhang et al. [10] with little modification. The tomatoes fruits were initially homogenized in blender prior to analysis.

About $5 \mathrm{~g}$ homogenized samples were extracted with methanol water solutions (4:1) after shaking on orbital shaker for about $30 \mathrm{mins}$ at $120 \mathrm{rpm}$ at room temperature. The subsequent mixtures were centrifuged and $100 \mu \mathrm{L}$ of the supernatant was buffered to $\mathrm{pH}$ 7.2. About $50 \mu \mathrm{L}$ of the buffered solution was then mixed with equal volume of conjugated aflatoxin-peroxidase in microtitre plate. These procedures were replicated three times and the sealed plates were incubated at $25{ }^{\circ} \mathrm{C}$ for $30 \mathrm{mins}$ in cold incubator.

The plates were further rinsed with phosphate buffer $(\mathrm{pH} 7.2)$ for 2 minutes before 50 $\mu \mathrm{L}$ of tetramethylbenzidine chromogen with $50 \mu \mathrm{L}$ of urea peroxide solution were added and incubated for another $30 \mathrm{~min}$ at $25{ }^{\circ} \mathrm{C}$ in cold incubator. About $100 \mu \mathrm{L}$ of $0.25 \mathrm{~mol} / \mathrm{dm}^{3}$ of sulphuric acid was added to terminate the reaction and the plates were 
read with spectrophotometer at $450 \mathrm{~nm}$ wavelength. The amounts of aflatoxins were evaluated from the previously prepared standard curve.

\section{Statistical Analysis}

The average value of the triplicate analysis for each sample was evaluated and presented in table. The data were subjected to statistical analysis using Statistical Package for Social Sciences (SPSS) version 21. The analysis of variance (ANOVA) was used to compared the differences among the values and further subjected to Duncan multiple range test (DMRT) to compare the mean values for significant difference. Differences were considered statistically significant at $\mathrm{P} \leq 0.05$ [11].

\section{Results and Discussions}

The results of aflatoxin contents and fungi contaminants presents in fresh and spoilt tomatoes samples were summarized in Table 1 below.

In fresh tomatoes samples, the aflatoxins level were below the limit of detection (LOD) value of $0.005 \mu \mathrm{g} / \mathrm{kg}$ of the analytical instrument for all the samples analyzed for sampling point $\mathrm{A}, \mathrm{B}$, and $\mathrm{C}$ (Table 1). While, the average value of aflatoxin contents in spoilt tomatoes were $8.17 \pm 0.57 \mu \mathrm{g} / \mathrm{kg}, 7.83 \pm 0.97 \mu \mathrm{g} / \mathrm{kg}$ and $8.62 \pm 0.69 \mu \mathrm{g} / \mathrm{kg}$ for samples obtained from sampling area D, E and F respectively (Table 1). However, the differences among the values obtained for the aflatoxin from these samples were not statistically significant $(\mathrm{p}>0.05)$.

Macroscopic and microscopic examination of the fungi isolates showed the presence of the following fungi as follows:

In the fresh tomatoes samples, Aspergillus niger, Fusarium sp, and Pencillium sp. were the three fungal species isolated from sample A and B respectively; while, the Aspergillus flavus, Mucor sp, alongside the Fusarium sp, were the three fungal species observed in sample C (Table 1).

Likewise, in the spoilt tomatoes samples, the following fungi groups were isolated: Aspergillus niger, Aspergillus parasiticus, Yeast, Fusarium sp, and Pencillium sp. were the five fungal species in sample D; Also in sample E, five fungal species were observed and they were Aspergillus niger, Aspergillus flavus, Pencillium sp., Fusarium $\mathrm{sp}$, and Yeast; while the four fungi isolates obtained from sample F were Aspergillus niger, Aspergillus flavus, Yeast, Fusarium sp. (Table 1). 
The effect of heat treatments on the level of aflatoxin contents of spoilt tomatoes were presented in Table 2 .

The non-significant reduction $(\mathrm{p}>0.05)$ in the average values of aflatoxin from $8.62 \pm$ $0.69 \mu \mathrm{g} / \mathrm{kg}$ to $7.97 \pm 0.41 \mu \mathrm{g} / \mathrm{kg}$ representing about $7.54 \%$ percentage reduction were observed after 5 minutes of heat treatment. At 15, 25 and 35 minutes after heat treatment, significant reduction $(\mathrm{p}<0.05)$ in aflatoxin level were observed with the values of $4.74 \pm 0.93 \mu \mathrm{g} / \mathrm{kg}, 4.04 \pm 0.43 \mu \mathrm{g} / \mathrm{kg}$ and $2.46 \pm 0.62 \mu \mathrm{g} / \mathrm{kg}$ represent about $45.01 \%, 53.13 \%$ and $71.46 \%$ percentage reduction respectively (Table 2).

Table 1 Aflatoxin contents and fungi contaminants of fresh and spoilt tomatoes samples

\begin{tabular}{|c|c|c|c|}
\hline $\begin{array}{c}\text { Sample } \\
\text { type }\end{array}$ & $\begin{array}{c}\text { Sampling } \\
\text { Point }\end{array}$ & $\begin{array}{c}\text { Average aflatoxin level } \\
(\mu \mathrm{g} / \mathrm{kg})\end{array}$ & Fungi isolates \\
\hline & $\bar{A}$ & $<\mathrm{LOD}$ & $\begin{array}{l}\text { Aspergillus niger, Fusarium } \\
\text { sp, Pencillium sp. }\end{array}$ \\
\hline \multirow[t]{3}{*}{ Fresh } & B & $<\mathrm{LOD}$ & $\begin{array}{l}\text { Aspergillus niger, Fusarium } \\
\text { sp, Pencillium sp., }\end{array}$ \\
\hline & C & $<\mathrm{LOD}$ & $\begin{array}{c}\text { Aspergillus flavus, Fusarium } \\
\text { sp, Mucor } \mathrm{sp} .\end{array}$ \\
\hline & D & $8.17 \pm 0.57^{\mathrm{a}}$ & $\begin{array}{l}\text { Aspergillus niger, } \\
\text { Aspergillus parasiticus, } \\
\text { Yeast, Fusarium } \mathrm{sp}, \\
\text { Pencillium sp. }\end{array}$ \\
\hline \multicolumn{4}{|l|}{ Spoilt } \\
\hline & $\mathbf{E}$ & $7.83 \pm 0.97^{\mathrm{a}}$ & $\begin{array}{c}\text { Aspergillus niger, } \\
\text { Aspergillus flavus, } \\
\text { Pencillium sp., Fusarium sp, } \\
\text { and Yeast }\end{array}$ \\
\hline & $\mathbf{F}$ & $8.62 \pm 0.69^{\mathrm{a}}$ & $\begin{array}{c}\text { Aspergillus niger, } \\
\text { Aspergillus flavus, Yeast, } \\
\text { Fusarium } \mathrm{sp}, \\
\end{array}$ \\
\hline
\end{tabular}

Results are presented as means \pm standard error of triplicate analysis; Means value with the same superscript shows no significance difference; LOD $=$ Limit of detection $=0.005 \mu \mathrm{g} / \mathrm{kg}$; significant level $=(\mathrm{p} \leq 0.05)$ 
Table 2 Effect of heat treatments on aflatoxin level of spoilt tomatoes

\begin{tabular}{ccc}
\hline $\begin{array}{c}\text { Treatment Period } \\
(\text { minutes })\end{array}$ & $\begin{array}{c}\text { Aflatoxin level } \\
(\boldsymbol{\mu g} / \mathbf{k g})\end{array}$ & $\begin{array}{c}\text { Heat treatment efficiency } \\
(\boldsymbol{\%})\end{array}$ \\
$\mathbf{0}$ & $8.62 \pm 0.69^{\mathrm{a}}$ & - \\
$\mathbf{5}$ & $7.97 \pm 0.41^{\mathrm{a}}$ & 7.54 \\
$\mathbf{1 5}$ & $4.74 \pm 0.93^{\mathrm{b}}$ & 45.01 \\
$\mathbf{2 5}$ & $4.04 \pm 0.43^{\mathrm{b}}$ & 53.13 \\
$\mathbf{3 5}$ & $2.46 \pm 0.62^{\mathrm{c}}$ & 71.46 \\
\hline
\end{tabular}

Results are presented as means \pm standard error of triplicate analysis; Means value with the same superscript shows no significance difference; LOD $=$ Limit of detection $=$ $0.005 \mu \mathrm{g} / \mathrm{kg} ;$ significant level $=(\mathrm{p} \leq 0.05)$

The presence of fungi contaminants were observed in all the tomatoes fruits samples purchased from the selected market area in Ilorin irrespective of the quality status of tomatoes sampled. The contamination of these products by fungi might occur majorly from its poor handling or due to vendors' attitude in Nigeria open market that barely subject their agricultural products to post-harvest decontamination treatments. Kaczarmarek et al. [12] has previously reported that the fungi are among the leading contaminants and potential spoilage agents of fruit products due to their preference for acidic condition that majorly characterized such products as tomatoes.

The most predominant fungal genera isolated from all the samples were Aspergillus and Fusarium spp, while Penicillum, Mucor, and Yeast were only present in some of the sample analysed. The predominant presence of Aspergillus spp. might have accounted for the incidence of aflatoxin in the tomatoes samples. Several authors have also reported the prevalence of aflatoxins producing Aspergillus spp. in fruit samples $[13,14,15]$.

The presence of these fungi contaminants in tomatoes fruit are of major economic and public health concerns, not only because of the roles they play in food spoilage but also as a potential source of fungal toxins. Adeyeye [16] stressed that fungi contaminations 
of various agricultural products could significantly reduce the value of such products and thereby lead to economic losses.

Furthermore, the aflatoxins contaminants were not detected in all the evaluated fresh tomatoes samples using the analytical instrument with $0.005 \mu \mathrm{g} / \mathrm{kg}$ limit of detection (LOD) value; whereas all the spoilt tomatoes samples were observed to be contaminated with aflatoxin. The average aflatoxin contents in spoilt tomatoes samples were 7.83 $\mu \mathrm{g} / \mathrm{kg}, 8.17 \mu \mathrm{g} / \mathrm{kg}$ and $8.62 \mu \mathrm{g} / \mathrm{kg}$ respectively, and the differences among these values were not statistically significant $(\mathrm{p}>0.05)$. Comparatively, these values were below the maximum allowable limits $(10 \mu \mathrm{g} / \mathrm{kg})$ for human consumption as the value adopted by National Agency for Food and Drug Administration in Nigeria from European Commission reported by Williams et al. [17].

Although, there were concerns about the consumption of aflatoxin contaminated food products to potentially contribute to high incidence rate of cancer among the people [7, 8]. However, proper cooking of pepper and tomatoes products for sauces making has been a common practice among Nigeria population most especially in the rural community. Therefore, the effect of heat treatment on aflatoxin level of spoilt tomatoes was further evaluated.

The effect heat treatments on the aflatoxin contaminated spoilt tomatoes at $100{ }^{\circ} \mathrm{C}$ under the standard conditions were observed to be time dependent. At 5 minutes period after boiling, about $7.5 \%$ non-significant reductions $(\mathrm{p}>0.05)$ in aflatoxin contents of the samples were observed. However, further heat treatment for about $15 \mathrm{~min}, 25 \mathrm{~min}$ and 35 min significantly $(\mathrm{p}<0.05)$ reduced the aflatoxin levels to about $45.0 \%, 53.1 \%$ and $71.5 \%$ respectively. This is an indication that proper cooking at $100{ }^{\circ} \mathrm{C}$, over a period of time can significantly reduce aflatoxin level in some food products that are usually subjected to cooking prior to consumption. In line with this finding, Diedhiou et al. [18] reported a significant reduction of about $82 \%$ in aflatoxin level of aflatoxin contaminated peanut after heat treatment over a specific period of time.

The significant reduction in aflatoxin level of spoilt tomatoes at $100{ }^{\circ} \mathrm{C}$ after 15,25 and 35 minutes of heat treatment, under normal atmospheric pressure, has shown that proper boiling might be an effective strategy of reducing the aflatoxin level of food products.

\section{Conclusion}


In spite of the effectiveness of heat treatment in the reduction of aflatoxin level of the aflatoxin contaminated spoilt tomatoes in this study, the most effective strategy to efficiently prevent aflatoxicosis in human is through consumption of fresh quality fruit products. Pre- and post-harvest treatment processes could also reduce the level of fungal infestation, spoilage and aflatoxin contamination of agriculture products.

\author{
Abbreviations \\ ELISA: Enzyme-linked immuno-sorbent assay; ${ }^{\circ} \mathrm{C}$ : degree Celcius; $\mu \mathrm{g} / \mathrm{kg}$ : microgram per kilogram; $\mathrm{p}$ : \\ probability level; < : less than; > greater than; LOD: limit of detection
}

\title{
Acknowledgements
}

Our sincere gratitude goes to Mr M. M. Mubarak for his assistance during the bench work of this study.

\section{Availability of data and material}

Please contact the corresponding author for any data request.

\section{References}

1. Udoh, I. P. et al., Ohanu, Studies on fungi responsible for the spoilage / deterioration of some edible fruits and vegetables. Advances in Microbiology, 2015. 5: p. 285-290.

2. Drusch, S. and W. Ragab, Mycotoxins in fruits, fruit juices and dried fruits. Journal of Food Protection, 2003. 66(8): p. 1514-1527.

3. Makun, H. A., et al., Fungal and aflatoxin contamination of some human food commodities in Nigeria. African Journal of Food Science, 2010. 4(4): p. 127-135.

4. Onuorah, S. and M. U. Orji, Fungi associated with the spoilage of post-harvest tomato fruits sold in major markets in Awka, Nigeria. Universal Journal of Microbiology Research, 2015. 3(2): p. $11-16$

5. Sadiq, S. I. and T. I. Aliyu, Comparative nutritional composition of raw and canned tomatoes Solanum lycopersicum (Lycopersicon esculentum) Dutse Market Jigawa State, Nigeria. Dutse Journal of Pure and Applied Sciences, 2018. 4(2): p. 424-433.

6. Danaan, V. V., Analysing poverty in Nigeria through theoretical lenses. Journal of Sustainable Development, 2018. 11(1): p. $20-31$.

7. Khoshpey, B., D. D. Farhud, and F. Zaini, Aflatoxins in Iran: nature, hazards and carcinogenicity. Iranian Journal of Public Health, 2011. 40(4): p. 1-30.

8. Kumar, P., et al., Aflatoxins: A global concern for food safety, human health and their management. Frontier in Microbiology, 2016. 7: p. 1-10.

9. Suleiman, M. S., et al., Fungi and Aflatoxin Occurrence in Fresh and Dried Vegetables Marketed in Minna, Niger State, Nigeria. Journal of Biochemistry and Physiology, 2017. 5(1): p. 1 - 4.

10. Zhang, W., et al., Screening a strain of Aspregillus niger and optimization of fermentation conditions for degradation of aflatoxin B1. Toxins, 2014. 6: p. 3158 -3172.

11. Ogbeibu, A. E. Biostatistics A Practical Approach to Research and Data Handling. Mindex Publishing Company Limited, Edo State, Nigeria, 2005. pp. 265.

12. Kaczmarek, M., S. V. Avery, and I. Singleton, Microbes associated with fresh produce: sources, types and methods to reduce spoilage and contamination. Advances in Applied Microbiology 2019. 107: p. 29-82. 
13. Muhammad, S., K. Shehu, and N. A. Amusa, Survey of the market diseases and aflatoxin contamination of tomato (Lycopersicon esculentum MILL) fruits in Sokoto, Northwestern, Nigeria. Nutrition and Food Science 2004. 32(2): p.72-76.

14. Abubakar, N., S. S. D. Mohammed, and Z. Ladan, Assessment of aflatoxins and aflatoxigenic fungi associated with dried vegetables from selected markets within Kaduna metropolis. Industrial Engineering 2017. 1(1): p. 8-13.

15. Suleiman, M. S., et al., Fungi and aflatoxin occurrence in fresh, semi-rotten and dried tomatoes in Dekina Local Government Area, Kogi State. Journal of Plant Biochemistry and Physiology 2017. 5(1): 1-4.

16. Adeyeye, S. A. O., Fungal mycotoxins in foods: A review. Journal of Cogent Food and Agriculture, 2016. 2: p. 1-11.

17. Williams, O. I., et al., Occurrence of Aflatoxin in some food commodities commonly consumed in Nigeria. Journal of Food Research, 2015. 4(5): p. 81-88.

18. Diedhiou, P. M., et al., Effect of different cooking methods on aflatoxin fate in peanut products. African Journal of Food Science and Technology, 2012. 3(2): p. 53-58. 